Revista de Economia Política, vol. 30, $n^{\circ} 3$ (119), pp. 491-510, julho-setembro/2010

\title{
Fluxos de investimento direto externo, competitividade e conteúdo tecnológico do comércio exterior da China no início do século XXI
}

\section{SAMANTHA FERREIRA E CUNHA CLÉSIO LOURENÇO XAVIER*}

\begin{abstract}
(1)
Foreign direct investment flow, competitiveness and technological structure of foreign trade in China in the beginning of the $21^{\text {st }}$ century. China's government introduced open market reforms in 1979, mediated by industrial policies improving the ability of attracting higher quality FDI (Foreign Direct Investment), which helped China's economy developing its technological capabilities. As a result, China's share in international trade rose impressively becoming third-largest trading nation in the world, by 2004, also its export structure is significantly more sophisticated. Facing the importance of understanding the determinants of developing word specialization patterns, this paper focuses on the competitiveness and technological structure of exports and imports by China for 1994-1998 and 2001-2005.

Keywords: China's Trade pattern; competitiveness; technological catching-up. JEL Classification: F14.
\end{abstract}

\section{INTRODUÇÃO}

A China iniciou as reformas de abertura econômica, transitando de uma economia fechada e planificada para uma economia aberta e orientada para o mercado, no final da década de 1970. Em 1992, o governo ampliou as reformas econômicas, com destaque para a redução gradativa das tarifas de comércio e a fixação da taxa de câmbio nominal em um nível que resulta em uma desvalorização real

\footnotetext{
* Professores do Instituto de Economia da Universidade Federal de Uberlândia. E-mails: cunhasf@ yahoo.com.bre clesio@ie.ufu.br. Submetido: Maio 2008; Aprovado: Fevereiro 2009.
} 
efetiva. ${ }^{1}$ Desde o início da abertura comercial, são observadas expressivas taxas de crescimento econômico da economia chinesa, sendo em média de $10 \%$ ao ano, considerando o período de 1980 a 2006. É a partir dos meados de 1990, então, com a segunda onda de reformas, que o fluxo de investimento direto externo (IDE) e as exportações chinesas cresceram de maneira surpreendente, sugerindo uma provável relação entre o IDE e o comércio exterior, e indiretamente, sobre o crescimento econômico.

Segundo dados do Banco Mundial, as exportações chinesas no período de 1983 a 1992 foram, em média, de US\$ 44 bilhões de dólares correntes, crescendo para US\$ 270 bilhões considerando os anos de 1993 a 2004. A evolução positiva do comércio exterior foi acompanhada pelo ingresso crescente de IDE (Investimento Direto Externo), o que reforçou por sua vez a expansão das exportações. Enquanto no período 1983-1992 a média anual dos fluxos de IDE foi de US\$ 3 bilhões de dólares correntes, no período 1993-2004 aumentou para US\$ 42 bilhões.

Ao mesmo tempo em que se verifica o aumento das exportações da China, identifica-se uma mudança na composição setorial de suas exportações em direção a setores intensivos em tecnologia e capital, em detrimento dos setores primários e intensivos em trabalho.

"À luz das mudanças observadas no comércio exterior chinês, a partir das reformas econômicas, com uma expansão da participação da China nos fluxos de comércio mundiais e a diversificação de sua pauta de exportações, o presente artigo possui um duplo objetivo: analisar a evolução do padrão de especialização comercial da China quanto à intensidade tecnológica, a partir de indicadores de competitividade do comércio internacional e verificar as características dos fluxos de IDE (Investimento Direto Externo) na China no período recente

Assim, busca contribuir com a discussão ao propor uma análise da competitividade da estrutura de comércio da China a partir da agregação dos setores segundo sua intensidade tecnológica, uma vez que os vários estudos que tratam do comércio chinês identificam uma mudança na composição setorial das exportações chinesas em direção aos setores mais intensivos em capital e tecnologia, a partir de indicadores de participação relativa que não dizem nada sobre a evolução da competitividade chinesa nesses setores. Portanto, pode-se levantar o seguinte questionamento: as mudanças na composição setorial da estrutura de comércio da China são acompanhadas por uma especialização das exportações chinesas em setores mais intensivos em capital e tecnologia? Em outras palavras, a China possui vantagens comparativas nos setores mais intensivos em capital e tecnologia?

\footnotetext{
${ }^{1}$ Durante a reforma, o governo promoveu a desvalorização da moeda chinesa em etapas. Em 1981 a taxa de câmbio era de Yuan 1.5/ Dólar, passando a Y 8.7 em 1994, e sendo fixada em 1995 no nível de Y 8.28 até ano de 2005, representando uma desvalorização frente ao dólar de $70 \%$ (Bransletter \& Lardy, 2006). De acordo com o relatório da OMC (2006), em julho de 2005 o governou anunciou uma revalorização do RMB em relação ao dólar em $2.1 \%$ e mudanças no regime cambial em direção a um regime mais flexível. Desde as mudanças anunciadas a taxa de câmbio nominal efetiva valorizou-se em cerca de $5 \%$.
} 
Procurando apresentar evidências sobre a importância dos fluxos de IDE para as mudanças observadas na estrutura setorial do comércio chinês, um segundo objetivo é analisar as características do IDE na China, procurando abordar as políticas de atração do IDE que estiveram presentes no processo de abertura econômica.

Para tanto, além desta breve introdução, o trabalho está divido em quatro seções. A segunda seção apresenta evidências sobre o comércio exterior da China, a partir de uma revisão da literatura recente sobre o tema, contemplando a importância das políticas de atração de IDE. A terceira seção descreve os procedimentos metodológicos utilizados. A quarta seção apresenta os resultados obtidos para a China em dois subperíodos: 1994-1998 e 2001-2005. A quinta seção trata das considerações finais.

\section{FLUXOS DE COMÉRCIO E INVESTIMENTO DIRETO EXTERNO NA CHINA}

As medidas de liberalização comercial aceleraram a expansão das atividades de processamento ${ }^{2}$ internacional, o que foi determinante da rápida diversificação das exportações de manufaturas. As atividades de processamento foram, inicialmente, atraídas para Zonas Especiais de Exportação ou Zonas Econômicas Especiais, áreas onde opera um regime fiscal diferenciado das demais empresas exportadoras do país, contemplando uma proteção efetiva. Os incentivos oferecidos pelo governo através das suas políticas de promoção das exportações estimularam a fragmentação da produção dos países vizinhos asiáticos que foram atraídos pelos baixos custos de mão de obra.

A participação das exportações de processamento no total das exportações da China era de $20 \%$ em meados de 1980 e aumentou para $60 \%$ em 2003, além disso, observou-se o crescimento contínuo da diversificação e sofisticação da pauta de comércio. É o que mostrou o estudo do IDB (2005), ao analisar o desempenho total das exportações, destacando o rápido crescimento, entre 1985-2002, dos setores de bens manufaturados, miscelânea de manufaturas (principalmente, artigos de vestuários, roupas e acessórios e calçados), maquinários e equipamento de transporte.

No início dos anos 1990, o setor de manufatura leve representava mais de $40 \%$ das exportações da China (calçados, vestuário, brinquedos e outros). Ao longo da década, a China obteve ganhos substanciais em outros setores mais sofisticados e a proporção das exportações chinesas representadas pelo setor de máquinas e transporte (incluindo eletrônicos) aumentou de 17\% em 1993 para 41\% em 2003, enquanto a proporção dos artigos manufaturados leves declinou de $42 \%$ para $28 \%$ (Rumbaugh \& Blancher, 2004). O mesmo é observado para o setor de

\footnotetext{
${ }^{2}$ Também denominadas "exportações de processamento" e "reexportações", referem-se ao processamento de produtos intermediários importados para a exportação de produtos finais.
} 
primários (alimentos, produtos agrícolas e combustíveis minerais) cuja participação no total das exportações reduziu-se de quase $50 \%$ em 1980 para menos de $10 \%$ em 2002 (Lundvall \& Gu, 2006).

Segundo a base de dados de comércio da CEPAL e utilizando a tipologia que classifica os setores do comércio segundo a intensidade tecnológica presente no trabalho de Lall (2000), a participação relativa das exportações de produtos primários apresentou uma queda expressiva ( $35 \%$ contra $4 \%$ ), contrabalançada pelo aumento da participação relativa das exportações de alta tecnologia $(2 \%$ contra $33 \%$ ), nos anos de 1985 e 2005, respectivamente (Tabela 1).

Tabela 1: Exportações da China segundo Intensidade Tecnológica - 1985-2005 (em \%)

\begin{tabular}{cccccc}
\hline Ano & $\begin{array}{c}\text { Produtos } \\
\text { primários }\end{array}$ & $\begin{array}{c}\text { Baseados em } \\
\text { recursos naturais }\end{array}$ & $\begin{array}{c}\text { Baixa } \\
\text { tecnologia }\end{array}$ & $\begin{array}{c}\text { Média } \\
\text { tecnologia }\end{array}$ & $\begin{array}{c}\text { Alta } \\
\text { tecnologia }\end{array}$ \\
\hline 1985 & $35,1 \%$ & $13,5 \%$ & $39,8 \%$ & $7,7 \%$ & $2,6 \%$ \\
1987 & $25,1 \%$ & $10,3 \%$ & $47,4 \%$ & $11,3 \%$ & $4,4 \%$ \\
1989 & $17,9 \%$ & $8,4 \%$ & $51,2 \%$ & $14,7 \%$ & $6,7 \%$ \\
1991 & $12,9 \%$ & $7,3 \%$ & $55,8 \%$ & $15,2 \%$ & $7,9 \%$ \\
1993 & $9,9 \%$ & $6,4 \%$ & $57,1 \%$ & $15,4 \%$ & $10,4 \%$ \\
1995 & $7,5 \%$ & $6,8 \%$ & $53,6 \%$ & $16,9 \%$ & $14,2 \%$ \\
1997 & $6,4 \%$ & $6,6 \%$ & $51,2 \%$ & $17,0 \%$ & $17,8 \%$ \\
1999 & $5,4 \%$ & $6,3 \%$ & $48,5 \%$ & $17,2 \%$ & $21,5 \%$ \\
2001 & $4,9 \%$ & $6,2 \%$ & $45,6 \%$ & $17,9 \%$ & $24,4 \%$ \\
2003 & $4,3 \%$ & $6,1 \%$ & $42,5 \%$ & $18,5 \%$ & $27,5 \%$ \\
2005 & $4,4 \%$ & $8,3 \%$ & $31,5 \%$ & $22,0 \%$ & $33,2 \%$ \\
\hline
\end{tabular}

Fonte: TradeCAN (2006).

O estudo de Lemoine \& Ünal-Kesenci (2002) evidenciou as maiores contribuições das atividades de processamento em termos setoriais no período de 1993-1999, sendo estas no setor de maquinário elétrico e outros instrumentos e equipamentos de transporte, concluindo que as mudanças na estrutura das exportações como um todo, diversificando-se em direção aos setores de maquinários refletem as mudanças ocorridas nas atividades de processamento, pois os setores tradicionais (têxteis e vestuários, couro e calçados) que apresentaram um desempenho abaixo da média das exportações em geral, também se caracterizam por uma baixa dependência de atividades de processamento.

O segundo fenômeno que envolve a ascensão da China no mercado internacional, além da expansão de suas exportações e sua diversificação em direção aos setores de maior conteúdo tecnológico é a diversificação de seus parceiros comerciais. Nos anos recentes, como mostrou Rumbaugh \& Blancher (2004), o superávit comercial com os Estados Unidos e a Europa aumentou significativamente no período de 1997-2002, ao mesmo tempo em que ampliou o déficit com a região 
asiática. Tais tendências permaneceram em 2003, em que os déficits com os países da Ásia continuaram a crescer, reduzindo o superávit comercial total da China que caiu $20 \%$ entre 2003 e 2002.

O crescimento do market-share da China no mercado dos Estados Unidos e da Europa está relacionado com a mudança da estrutura de suas exportações em direção aos maquinários, telecomunicações e bens de consumo eletrônicos e equipamentos de informática. Por outro lado, o déficit nos mercados em desenvolvimento reflete o crescimento da demanda chinesa por commodities primárias (como óleo bruto e cobre), bens intermediários (componentes de produtos eletrônicos e outros bens de consumo duráveis), e bens de capital (em consequência das elevadas taxas de investimento da economia) (Eichengreen et al., 2004).

Em relação ao déficit crescente com os vizinhos asiáticos, Lemoine \& ÜnalKesenci (2002) argumentam que a política utilizada pelo governo chinês para a promoção das exportações no início do período de reformas, beneficiando as atividades de processamento, estimulou a fragmentação e reorganização das atividades da indústria dentro da Ásia. Em 1999, a região da Ásia era a maior exportadora de insumos para as atividades de processamento na China, com uma participação de $40 \%$ de Hong Kong, Taiwan e Coreia do Sul e $25 \%$ do Japão, sendo que aproximadamente $70 \%$ das exportações da região da Ásia e $55 \%$ do Japão foram direcionadas para as indústrias de exportações de processamento e não para o mercado interno chinês, o que indica uma intensificação do comércio entre a Ásia e a China em razão da divisão internacional da cadeia de valor adicionado na região. Do lado dos países desenvolvidos, Estados Unidos e Europa quase não contribuem como fornecedores de bens intermediários para atividades de processamento, mas são os principais importadores das reexportações realizadas pela China, revelando esta ser uma estratégia da região asiática para atingir mercados dos países desenvolvidos.

As políticas de atração de investimentos estrangeiros fazem parte da estratégia do governo de promoção das exportações da China. Nos anos iniciais da reforma econômica, o governo estimulava o estabelecimento de firmas estrangeiras em atividades de processamento e zonas econômicas especiais, através de tarifas preferenciais, exigindo, em contrapartida, que as firmas alcançassem determinados níveis de exportações em relação à produção, geralmente, essa razão era de $70 \%$. O sistema de tarifas administrado pelo governo ainda prevê a isenção de tarifas de importação sobre partes e componentes utilizados nas atividades de processamento. A proporção das exportações que se beneficiam de insumos importados isentos de tarifas de importação cresceu continuamente, atingindo $55 \%$ em 2003, segundo dados do IDB (2005). ${ }^{3}$

\footnotetext{
${ }^{3}$ Trata-se de medidas diversas com o objetivo comum de atrair o IDE orientado para exportações: de um lado, as zonas econômicas especiais que oferecem vantagens tarifárias, como o imposto de renda de pessoa jurídica em níveis reduzidos, de outro lado, as medidas de "drawback" para exportadores, sendo uma sistemática de isenção tarifária. (IDB, 2005)
} 
A entrada de IDE (Investimento Direto Externo) na China estava restrita à formação de joint-ventures entre as firmas estrangeiras e as empresas domésticas, conforme legislação de 1979. À época foram criadas quatro "zonas econômicas especiais" que combinavam vantagens tarifárias e uma participação no comércio internacional relativamente liberalizada. A iniciativa logrou sucesso em atrair os investidores estrangeiros, o que levou o governo a criar zonas especiais adicionais, dentre as principais, vale destacar "Economic and Technical Development Zones" e "High Tecnhology Development Zones", ${ }^{4}$ que são reguladas pelo governo central e local e oferecem menos vantagens que as "zonas econômicas especiais" (IDB, 2005; Branstetter \& Lardy, 2006).

As políticas de atração do IDE faziam parte de uma estratégia mais ampla de incentivo à entrada de investimentos produtivos em setores específicos da economia e de promoção de avanços tecnológicos. Nesse sentido, o governo instituiu mudanças na regulação sobre o IDE que consistiram em uma maior liberalização segundo "categorias" criadas para o IDE. As firmas estrangeiras envolvidas em "projetos orientados para exportação" e "projetos tecnologicamente avançados" recebiam benefícios adicionais (Branstetter \& Lardy, 2006).

O trabalho de $\mathrm{Lu}$ (2000) aborda com mais detalhe a política sistemática de atração de IDE seletiva para determinados setores, que ganhou importância na década de 1990. Os projetos que receberam tratamento preferencial do governo envolveram a indústria de alta tecnologia e o desenvolvimento da infraestrutura, como os setores de transporte, telecomunicações e energia. Além desses, os projetos de incentivo às exportações e de substituição das importações também foram estimulados. Em princípio, o governo dividiu os projetos fundados em capitais externos em quatro categorias: os projetos que serão fomentados, os que serão permitidos, os que serão restringidos e os que serão proibidos. Em relação ao sistema de tarifas, observou-se que a indústria de manufaturas e a indústria leve apresentaram tarifas cinco vezes menores do que o total da indústria.

Quanto às mudanças estruturais observadas ao longo da década de 1990, considerando a distribuição setorial dos fluxos de IDE, notou-se que a participação da indústria de manufaturas no total de IDE variou entre $45 \%$ e $85 \% .{ }^{5}$ Destaca-se a elevação da participação nas indústrias de utilidade pública e serviços,

\footnotetext{
${ }^{4}$ As "Zonas Econômicas Especiais" foram criadas no início das reformas, em 1980. Depois delas outras zonas especiais surgiram, diferenciando-se uma das outras, sobretudo, quanto ao grau de vantagens tarifárias oferecidas e de restrições à atuação das firmas estrangeiras. Tais zonas adicionais ampliaram a entrada de IDE ao permitirem a aprovação de projetos de investimentos externos em nível provincial. Mas seu papel de destaque deve-se à sua relação com as políticas de inovação e desenvolvimento tecnológico, sendo que a maior parte das exportações de alta tecnologia da China tem origem em tais zonas especiais.

${ }^{5}$ Em relação à distribuição setorial do IDE na China, o estudo do IDB (2005) apontou para a ampliação da participação das firmas estrangeiras em indústrias intensivas em capital e tecnologia, igual a $77 \%$, em detrimento das indústrias intensivas em trabalho e de baixo valor agregado, igual a $23 \%$, no final dos anos 1990. Tais mudanças, segundo o estudo, explicariam o aumento da participação das exportações de alta tecnologia no total das exportações de manufaturas da China nos anos 2000.
} 
construção, transportes e telecomunicações. Além disso, o autor chama atenção para a mudança na composição do comércio exterior de setores primários em direção às manufaturas. Tais resultados permitem concluir que as políticas industriais implantadas ao longo da década de 1990, em período anterior à entrada da China na OMC, foram eficientes no direcionamento do investimento estrangeiro para as indústrias consideradas prioritárias e, portanto, na promoção de mudanças estruturais desejáveis.

Com o relaxamento das restrições ao longo dos anos, viu-se na década de 90 o crescimento das firmas de propriedade totalmente estrangeira sobre o tipo joint-venture na composição dos fluxos de IDE. As negociações da entrada da China na OMC garantiram maior liberalização sobre os investidores estrangeiros, o que também explica o boom observado nos fluxos de IDE para o país a partir do ano 2000. O processo de adesão da China à Organização Mundial do Comércio (OMC) foi concluído em 2002. Dentre os compromissos assumidos, pode-se destacar a redução gradual e eliminação das tarifas sobre os bens importados e das quotas de importação, a abertura de seu mercado de serviços, a eliminação das políticas preferenciais impostas aos investidores estrangeiros e produtos importados, o fortalecimento da lei de propriedade intelectual, a eliminação de subsídios às exportações, dentre outros aspectos.

Portanto, analisando a trajetória do IDE desde os anos da abertura até o período recente, observou-se a intensificação dos fluxos de IDE na China a partir de meados dos anos 1990, com a segunda onda de reformas econômicas, sendo que a entrada de IDE continuou sua trajetória ascendente até o ano de 2005 (Tabela 2). Em relação à participação do fluxo de IDE da China nos fluxos recebidos pelos países em desenvolvimento e a região da Ásia e Oceania, percebeu-se que a participação da China cresceu significativamente ao longo do período, atingindo seu auge em 2002. Além disso, é possível notar a importância da China como o maior receptor na região do Leste Asiático, com uma participação superior a 50\%.

Tabela 2: Fluxos de Investimento Direto Externo na economia chinesa

\begin{tabular}{|c|c|c|c|c|c|c|c|}
\hline & $\begin{array}{c}1980 / \\
1992(a)\end{array}$ & $\begin{array}{c}1993 / \\
2001(a)\end{array}$ & 2002 & 2003 & 2004 & 2005 & 2006 \\
\hline IDE China (US\$ milhões) & 2.696 & 39.906 & 52.743 & 53.505 & 60.630 & 72.406 & 69.468 \\
\hline \multicolumn{8}{|l|}{ Participação no total (\%) } \\
\hline Mundo & 2,4 & 6,2 & 8,5 & 9,5 & 8,2 & 7,7 & 5,3 \\
\hline $\begin{array}{l}\text { Países em } \\
\text { Desenvolvimento }\end{array}$ & 10,5 & 23,6 & 31,7 & 29,9 & 21,4 & 23,0 & 18,3 \\
\hline Ásia e Oceania & 17,6 & 41,0 & 53,6 & 46,4 & 35,5 & 34,6 & 26,7 \\
\hline Leste Asiático & 44,2 & 61,6 & 77,9 & 73,6 & 57,0 & 62,3 & 55,2 \\
\hline
\end{tabular}

(a) Média simples

Fonte: UNCTAD, World Investment Directory (2007). 
Tabela 3: Fusões e Aquisições e Fluxos de IDE - China - 1990-2006 - Em US\$ milhões

\begin{tabular}{cccc}
\hline Ano & Fluxos de IDE & Fusões e Aquisições & Part. (\%) \\
\hline 1990 & $3.487,11$ & 8,00 & $0,2 \%$ \\
1992 & $11.007,51$ & 221,10 & $2,0 \%$ \\
1994 & $33.766,50$ & 714,90 & $2,1 \%$ \\
1996 & $41.725,52$ & $1.905,50$ & $4,6 \%$ \\
1998 & $45.462,75$ & 797,80 & $1,8 \%$ \\
2000 & $40.714,81$ & $2.247,00$ & $5,5 \%$ \\
2002 & $52.742,86$ & $2.072,45$ & $3,9 \%$ \\
2004 & $60.630,00$ & $6.768,39$ & $11,2 \%$ \\
2006 & $69.468,00$ & $6.723,76$ & $9,7 \%$ \\
\hline
\end{tabular}

Fonte: UNCTAD, World Investment Directory (2007).

A capacidade que os investimentos estrangeiros têm de contribuir para o crescimento da economia está relacionado à natureza desse investimento, no caso da economia chinesa, eles foram majoritariamente do tipo greenfield, isto é, foram destinados à aquisição de novos ativos. Durante o período de 1990 a 2006, segundo dados da UNCTAD, a participação de F\&A (Fusões e Aquisições) sobre o total dos fluxos de IDE oscilou entre $1 \%$ e $11 \%$, o que significa que cerca de $90 \%$ do IDE que entrou na China foi, principalmente, destinado a modernização e ampliação da capacidade produtiva existente (Tabela 3 ).

Uma das expectativas associadas à presença das empresas estrangeiras que possuem vantagens sobre as firma domésticas quanto a técnicas mais avançadas e acesso aos mercados globais, é a ampliação da participação do país receptor no comércio internacional, o que foi verificado no caso da economia chinesa. A participação das firmas estrangeiras no total das exportações chinesas apresentou durante o período de 1995 a 2005 uma trajetória ascendente, representando mais da metade das exportações totais da China. Do lado das importações, o coeficiente também é elevado, mas como existe a contrapartida do lado das exportações, não há um constrangimento à balança comercial. Pode-se dizer que parcela considerável do IDE que entrou na China, a despeito do potencial mercado consumidor chinês, visou atender o mercado externo. Além disso, os coeficientes de exportação e importação elevados indicam a importância dos fluxos de comércio intraindustrial, o que está relacionado à participação da China nas cadeias de produção regionais (Tabela 4). 
Tabela 4: Participação das Empresas Estrangeiras no Comércio Exterior da China - 1995-2005

\begin{tabular}{|c|c|c|c|c|c|c|}
\hline \multirow[b]{3}{*}{ Ano } & \multirow{2}{*}{\multicolumn{2}{|c|}{$\begin{array}{l}\text { Empresas Estrangeiras } \\
\text { US\$ } 100 \text { milhões }\end{array}$}} & \multicolumn{2}{|l|}{ Total } & \multirow{2}{*}{\multicolumn{2}{|c|}{ Part.(\%) }} \\
\hline & & & & & & \\
\hline & Exp & Imp & Exp & Imp & Exp & Imp \\
\hline 1995 & 468,76 & 629,43 & $1.487,8$ & $1.320,8$ & $32 \%$ & $48 \%$ \\
\hline 1997 & 749,00 & 777,21 & $1.827,9$ & $1.423,7$ & $41 \%$ & $55 \%$ \\
\hline 1999 & 886,28 & 858,84 & $1.949,3$ & $1.657,0$ & $45 \%$ & $52 \%$ \\
\hline 2001 & $1.332,35$ & $1.258,63$ & $2.661,0$ & $2.435,5$ & $50 \%$ & $52 \%$ \\
\hline 2003 & $2.403,06$ & $2.318,64$ & $4.382,3$ & $4.127,6$ & $55 \%$ & $56 \%$ \\
\hline 2005 & $4.441,83$ & $3.874,56$ & $7.619,5$ & $6.599,5$ & $58 \%$ & $59 \%$ \\
\hline
\end{tabular}

Fonte: National Bureau of Statistics of China. Disponível em: <http://www.stats.gov.cn/english/>

Assim, o presente estudo busca avançar na análise da competitividade e dinamismo do padrão de especialização comercial da China, a partir do cálculo de indicadores de especialização comercial, considerando a importância desses resultados para a definição de políticas industriais, conformando uma inserção externa virtuosa, isto é, concentrada em setores dinâmicos do comércio mundial.

\section{PROCEDIMENTOS METODOLÓGICOS}

Para análise da especialização comercial da China são realizados os cálculos para os indicadores de Vantagens Comparativas Reveladas (VCR) e Contribuição ao Saldo Comercial (CS). As fórmulas dos indicadores podem ser escritas como:

$$
V C R=\frac{X i j / X j}{X i / X}
$$

Onde Xij representam as exportações totais do setor "i" realizadas pelo país “j”; Xi são as exportações mundiais totais do setor "i”; Xj são as exportações totais realizadas pelo país “j” e $\mathrm{X}$ representam as exportações mundiais totais.

O índice de Vantagens Comparativas Reveladas (VCR) desenvolvido por Balassa (1965) é uma medida de especialização do comércio internacional. O indicador é uma comparação da estrutura de exportações do país em questão com uma determinada zona de referência geográfica, no caso da presente artigo, o mercado mundial. Sob a concepção teórica de que as diferentes dotações de fatores entre os países conformam uma estrutura característica de exportações, os resultados obtidos procurariam expressar "a posteriori" as vantagens relativas de custos dos diferentes países a partir de suas especializações comerciais. Nesse sentido, o indicador de VCR é apenas uma variável de resultado, a qual tenta captar no âmbito do mercado os efeitos finais do comércio internacional (Xavier, 2000, p. 36)

$\mathrm{O}$ indicador de VCR apresentará um resultado superior ou inferior à unidade. 
Se o país “j” possuir uma vantagem comparativa no setor "i” em relação à economia mundial, então, o indicador de VCR será maior que um $(1<V C R<\infty)$. Analogamente, se o indicador de VCR for menor que um $(0 \leq V C R<1)$, o país não apresentará vantagens comparativas. Se o indicador foi igual à unidade, então, a participação do país (j) nas exportações mundiais do setor (i) é idêntica à participação das exportações totais do país (j) no total das exportações mundiais, indicando ausência de vantagens ou desvantagens comparativas no comércio mundial.

Em relação à limitação do indicador de VCR que considera, exclusivamente, o fluxo de exportações do país no cálculo de sua posição competitiva, sem fazer nenhuma referência ao fluxo de importações, Balassa (1965) argumentou que considerar os valores de importações envolvia dificuldades relacionadas à aplicação heterogênea de subsídios, quotas e outras barreiras ao comércio pelos países. Todavia, Lafay (1990) apontou que os fluxos de exportações também estariam sujeitos a vieses originários em razão dos diferentes níveis de proteção (às exportações) que podem ser adotados pelos diferentes países.

Em razão disso, o estudo também considera para análise dos resultados um segundo indicador de vantagens comparativas baseado em saldos comerciais e não apenas nos fluxos de exportações. Trata-se do indicador de Contribuição ao Saldo (CS), desenvolvido por Lafay (1990), que poder ser obtido pela fórmula:

$$
C S=(1000 / P I B j) *\{(X i j-M i j)-[((X i j+M i j) /(X j+M j) *(X j-M j))]\}
$$

Onde Xij são as exportações totais do setor "i” realizadas pelo país “j”; Mij são as importações totais do setor "i" realizadas pelo país "j"; $\mathrm{Xj}$ representam as exportações totais realizadas pelo país " $\mathrm{j}$ ”; $\mathrm{Mj}$ representam as importações totais realizadas pelo país "j” e PIBj corresponde ao Produto Interno Bruto do país “j”.

$\mathrm{O}$ indicador de CS também procura expressar "a posteriori" as vantagens relativas de diferentes países a partir de suas diferentes competitividades setoriais (Xavier, 2000). Trata-se da mensuração da contribuição ao saldo em termos relativos, e não da estimação do saldo comercial em termos absolutos, que é obtido a partir da diferença entre o valor das exportações e importações. Procura-se verificar se o grupo setorial contribui positivamente ou negativamente para formação do saldo corrente global.

Observando a equação acima, a ponderação feita pelo PIB do país visa minimizar os efeitos do comércio intra-industrial (fluxos minoritários) sobre o saldo comercial, permitindo a comparação dos valores obtidos ao longo dos setores e países. Além disso, a expressão é multiplicada por (1000/PIBj) para se chegar ao valor do indicador de CS. Se o indicador de CS for positivo (CS >0), o país apresentará vantagens comparativas em determinado grupo setorial, caso contrário, seu resultado apresentará um valor negativo $(C S<0)$ e o país não possuirá vantagens. Uma inserção externa virtuosa pressupõe além de o país exportar em setores dinâmicos do mercado mundial, que suas exportações contribuam positivamente para geração de saldo comercial. 
Para a classificação das exportações de setores industriais com base em parâmetros tecnológicos adotou-se como critério de agregação dos dados a tipologia presente no artigo de Laplane et al. (2001), elaborada com base em Pavitt (1984).

Em Holland e Xavier (2004), os grupos de setores/ indústrias, com base no critério de agregação, são apresentados como se segue:

a) "Produtos primários": agrícolas, minerais e energéticos;

b) "indústria intensiva em recursos naturais”: indústria agroalimentar, indústria intensiva em outros recursos agrícolas, indústria intensiva em recursos minerais e indústria intensiva em recursos energéticos. A principal característica deste grupo é a existência de uma oferta elástica de matéria-prima como determinante das "vantagens comparativas" de um país ou de uma região;

c) "indústria intensiva em trabalho" (ou "tradicionais”): os quais estão concentrados os mais tradicionais bens industriais de consumo não duráveis como têxteis, confecções, couro e calçados, cerâmica, editorial e gráfico, produtos básicos de metais, entre outros. O grupo se caracteriza pelo fato de que o preço é o principal fator competitivo, nesse sentido, a escolha das trajetórias tecnológicas está relacionada à capacidade das inovações de processo, originadas nos setores fornecedores de equipamentos e materiais, de minimizar os custos;

- estes dois grupos anteriores correspondem ao grupo "dominado pelos fornecedores”, na classificação Pavitt original, pois se caracterizam por uma fraca capacidade de P\& D e engenharia, sendo considerados absorvedores líquidos de tecnologia, uma vez que suas inovações têm origem na compra de equipamentos e insumos intermediários.

d) "indústria intensiva em escala": inclui a indústria automobilística, a indústria siderúrgica e os bens eletrônicos de consumo. A presença de grandes empresas oligopólicas com elevada intensidade de capital, amplas economias de escala de processo, learning e organizacionais, bem como uma elevada complexidade nas atividades de engenharia, caracterizam este grupo;

e) "fornecedores especializados": inclui bens de capital sob encomenda e equipamentos de engenharia e são caracterizados pela elevada obtenção de economias de escopo, alta diversificação da oferta geralmente concentrada em empresas de médio porte, mas com uma notável capacidade de inovação de produto. Em sua maioria são empresas que desenvolvem estreito relacionamento com os usuários, com alta capacitação interna e domínio específico da tecnologia de projeto e engenharia; e

f) “indústria intensiva em P\&D”: faz parte deste grupo os setores de química fina (produtos farmacêuticos, entre outros), componentes eletrônicos, telecomunicações e indústria aeroespacial, os quais são todos caracterizados por atividades inovativas diretamente relacionadas com elevados gastos em P\&D, tendo suas inovações de produto um alto poder de difusão sobre o conjunto do sistema econômico.

A metodologia apresentada converge à classificação internacional SITC, Revisão 3, classificando cerca de 260 setores do comércio internacional, segundo parâmetros tecnológicos, em onze subgrupos, a saber: "produtos primários agrícolas", "produtos primários minerais”, "produtos primários energéticos”, "indús- 
tria agroalimentar", "indústria intensiva em outros recursos agrícolas", "indústria intensivo em recursos minerais", "indústria intensiva em recursos energéticos", "indústria intensiva em trabalho", "indústria intensiva em escala", "fornecedores especializados" e "indústria intensiva em P\& D".

Alguns setores não foram considerados na agregação, sejam eles, os setores da Revisão 3: "Gás de carvão/ Gás da água/ etc." (SITC 345), "Pacotes Postais Não Classificados" (SITC 911) e "Transações Especiais Não Especificadas” (SITC 931), por conta das dificuldades de classificá-los adequadamente. Ademais, quando os países comercializam em algum desses setores, geralmente, sua participação em relação ao total do comércio tem pouca importância, não afetando os resultados obtidos.

A utilização de tal procedimento metodológico, que agrega cerca de 260 setores de exportação em onze subgrupos, está relacionada ao objetivo do presente artigo que é analisar as mudanças na composição setorial da pauta de exportações da China em direção aos setores intensivos em tecnologia. A partir do cálculo dos indicadores de comércio internacional, como VCR e CS, considerando os grupos de setores da tipologia Pavitt, busca-se avaliar se as mudanças verificadas na composição setorial das exportações foram acompanhadas por um incremento da competitividade da China nos setores mais intensivos em tecnologia. Ademais, uma estrutura de exportações mais intensiva em tecnologia resulta em ampliação da participação no comércio mundial, bem como no desenvolvimento industrial de um país.

\section{COMPETITIVIDADE NO COMÉRCIO EXTERIOR DA CHINA}

A presente seção apresenta os indicadores de Vantagem Comparativa Revelada (VCR) e Contribuição ao Saldo (CS), obtidos a partir da média simples das exportações e importações nos períodos 1994-1998 e 2001-2005. Tais indicadores são complementares e permitem estabelecer uma interação entre a especialização comercial do país e a geração de saldos comerciais. A análise do padrão de especialização, nessa perspectiva, permite concluir sobre as possibilidades de mudanças na estrutura das exportações chinesas. Além disso, os setores de exportação e importação foram classificados através da metodologia Pavitt (1984) adaptada para o comércio exterior já apresentada, reduzindo os setores do comércio internacional em onze subgrupos com base em parâmetros tecnológicos.

A Tabela 5 informa os valores de VCR obtidos para a média simples das exportações agrupadas segundo a intensidade tecnológica. No primeiro período, apenas os grupos "produtos primários agrícolas" e "indústria intensiva em trabalho" apresentaram um VCR maior que a unidade, indicando que o país é competitivo nesses setores, destacando-se: dentre os primários, peixes, verduras, chá e mate; dentre os intensivos em trabalho, artigos têxteis, malas para diversos fins, vestuário masculino e feminino, couro e calçados. No segundo período, a China deixa de ser competitiva em "produtos primários agrícolas", mantendo um alto VCR em "indústria intensiva em trabalho" e passa a ser competitiva na indústria "fornecedores especializados". 
Tabela 5: Indicador de Vantagem Comparativa Revelada (VCR) - China - 1994-1998 e 2001-2005

\begin{tabular}{lcc}
\hline Tipologia Pavitt & $1994-1998$ & 2001-2005 \\
\hline "Produtos Primários Agrícolas" & 1,0619 & 0,6332 \\
"Produtos Primários Minerais" & 0,6187 & 0,4418 \\
"Produtos Primários Energéticos" & 0,6903 & 0,2314 \\
"Indústria Agroalimentar" & 0,6387 & 0,5359 \\
"Indústria Intensiva em Outros Recursos Agrícolas" & 0,6676 & 0,4660 \\
"Indústria Intensiva em Recursos Minerais" & 0,7694 & 0,6742 \\
"Indústria Intensiva em Recursos Energéticos" & 0,4375 & 0,4444 \\
"Indústria Intensiva em Trabalho" & 2,8548 & 2,1582 \\
"Indústria Intensiva em Escala" & 0,7316 & 0,8499 \\
"Fornecedores Especializados" & 0,5753 & 1,3012 \\
\hline "Indústria Intensiva em P\&D" & 0,5265 & 0,8051 \\
\hline
\end{tabular}

Fonte: Elaboração própria, a partir de COMTRADE/ UNCTAD.

O trabalho de Lemoine \& Ünal-Kesenci (2002) aborda a estrutura de comércio exterior da China em termos da composição por estágio da produção, com o objetivo de identificar se a China desenvolveu uma "especialização vertical" ou uma "especialização horizontal”, isto é, a primeira acontece quando o país possui vantagem comparativa em algumas etapas da produção e desvantagem em outras, enquanto a última acontece quando o país possui vantagem comparativa em todas as etapas da produção de um determinado produto, à jusante e à montante. Considerados 98 setores da classificação HS (Harmonized System), foram reagregados em 17 grupos de setores. Para cada grupo (por exemplo, produtos agrícolas brutos, produtos alimentícios, couro e calçados etc.) foram considerados os estágios da produção (produtos primários, produtos intermediários e produtos acabados). Os resultados encontrados mostraram que o padrão de vantagem comparativa da China, como um todo, se caracterizou por uma "especialização vertical”. Em termos desagregados, a indústria têxtil e de vestuário apresentou a maior vantagem comparativa, corroborando os resultados encontrados aqui.

Em relação ao VCR obtido na indústria "fornecedores especializados”, esse foi "puxado" pelos setores de maquinários (máquinas de escritório e equipamentos de informática) e maquinários elétricos, pertencentes ao capítulo 7 da classificação SITC. Isso demonstra que a China está melhorando sua competitividade em produtos intensivos em tecnologia. Lemoine \& Ünal-Kesenci (2002) também apontaram essa mudança ao verificarem que houve, entre 1997 e 1999, um ligeiro crescimento das exportações chinesas de bens de capital, em detrimento das exportações de bens de consumo. 
A Tabela 6 apresenta os valores obtidos para o indicador de CS. Percebeu-se que, no primeiro período, apenas os subgrupos "produtos primários agrícolas", "indústria intensiva em trabalho", com um valor bem superior $(44,5)$ e "indústria intensiva em escala" apresentaram uma contribuição positiva ao saldo comercial. No segundo período, o subgrupo "produtos primários agrícolas" passou a contribuir negativamente para o saldo, sendo que seu resultado desfavorável foi contrabalançado pelo incremento do índice de CS nos subgrupos "indústria intensiva em trabalho" (cresceu de 44,5 para 67,4) e "indústria intensiva em escala" (cresceu de 4,0 para 17,4), além disso, os subgrupos "fornecedores especializados" e "indústria agroalimentar" passaram a apresentar uma contribuição positiva ao saldo, apesar de seus valores bem inferiores $(0,7$ e 0,8 respectivamente).

Tabela 6: Indicador de Contribuição ao Saldo Comercial (CS) - China - 1994-1998 e 2001-2005

\begin{tabular}{lcc}
\hline Tipologia Pavitt & $1994-1998$ & 2001-2005 \\
\hline "Produtos Primários Agrícolas" & 2,4328 & $-3,3584$ \\
"Produtos Primários Minerais" & $-6,0460$ & $-10,7689$ \\
"Produtos Primários Energéticos" & $-0,5009$ & $-13,3521$ \\
"Indústria Agroalimentar" & $-2,2583$ & 0,7035 \\
"Indústria Intensiva em Outros Recursos Agrícolas" & $-1,6170$ & $-2,8584$ \\
"Indústria Intensiva em Recursos Minerais" & $-2,5072$ & $-8,6922$ \\
"Indústria Intensiva em Recursos Energéticos" & $-1,9237$ & $-2,4052$ \\
"Indústria Intensiva em Trabalho" & 44,5688 & 61,4293 \\
"Indústria Intensiva em Escala" & 4,0752 & 17,4725 \\
"Fornecedores Especializados" & $-23,4086$ & 0,8908 \\
\hline "Indústria Intensiva em P\&D" & $-12,2510$ & $-38,5569$ \\
\hline
\end{tabular}

Fonte: Elaboração própria, a partir de COMTRADE/ UNCTAD.

A apresentação agregada da análise de VCR e CS, de fato, não revela muito sobre a competitividade, mas quando se observa os dados desagregados, corrobora-se a suspeita de que a China está melhorando sua competitividade nos setores mais intensivos em tecnologia. Considerando o ranking de setores ordenados de maneira decrescente segundo seu valor de VCR, dentre as vinte primeiras posições, contatou-se que eram ocupadas por manufaturas leves intensivas em trabalho, com destaque para vestuários e têxteis, e alguns produtos primários. Já no segundo período, durante 2001 a 2005, aparecem ao lado dos setores de baixa tecnologia, os setores: equipamentos de informática, veículos, gravadores de som/ TV, equipamentos domésticos, pertencentes à "indústria intensiva em escala" e "fornecedores especializados". Em relação ao indicador de CS, vale destacar: equi- 
pamentos de informática, que apresentou a maior contribuição positiva em 2001-2005, e na quinta posição, equipamentos de telecomunicações, que pertencem à "indústria intensiva em P\&D".

Pode-se dizer que os resultados encontrados em termos da contribuição ao saldo comercial convergiram aos resultados em termos do índice de vantagens comparativas reveladas, pois os setores que contribuíram positivamente para o saldo, também foram aqueles em que a China mostrou-se competitiva. A única exceção foi o caso da "indústria agroalimentar" e "indústria intensiva em escala" que apresentaram um índice de CS positivo, mas um índice de VCR menor que a unidade, indicando uma desvantagem comparativa, todavia, os valores obtidos do CS, apesar de positivos, foram muito próximos de zero.

Procurando avaliar se o padrão de especialização comercial da China convergiu ou não à evolução das exportações mundiais, utilizou-se uma metodologia aplicada no artigo de Baumann \& Neves (1998), identificando uma relação entre os setores em que o país tornou-se mais competitivo e aqueles setores com maior potencial de crescimento da demanda externa. Para isso, é construída uma matriz que relaciona as exportações mundiais totais de um determinado setor (que se supõe ser igual às importações mundiais) e o indicador de market-share do país em determinado setor.

A matriz de competitividade distingue, então, quatro quadrantes, segundo os quais os setores de exportação do país são classificados: "setores em retrocesso", representando o grupo de setores no qual ocorre uma taxa de crescimento abaixo da média do mercado mundial seguida de uma diminuição da parcela de mercado do país nestes setores; "setores em declínio", referem-se ao grupo de setores com taxa de crescimento abaixo da média do mercado mundial nos quais ocorre um crescimento da parcela de mercado das exportações do país; "setores em situação ótima", representando o grupo de setores que apresentam, simultaneamente, uma taxa de crescimento acima da média do mercado mundial e um aumento da fatia de mercado do país nestes setores; “oportunidades perdidas”, referem-se ao grupo de setores dinâmicos (ou seja, que apresentaram variações positivas) no mercado mundial, em que o país perdeu market-share.

Em relação às limitações que envolvem a matriz de competitividade, deve-se dizer que ela é sensível aos períodos de tempo escolhidos e ao nível de agregação dos dados. No caso desta pesquisa, a matriz foi construída comparando os quinquênios: 1994-1998 e 2001-2005. A zona de referência geográfica é o mercado mundial, sendo os setores desagregados a três dígitos.

A Tabela 7 refere-se à matriz de competitividade da China para os períodos já especificados. Com base na matriz de competitividade, o país é classificado como competitivo ou não-competitivo e o setor é classificado como dinâmico ou não dinâmico. Trata-se da análise da inserção do país no mercado mundial e da classificação dos setores segundo a capacidade competitiva do país.

Observou-se que, em 1994-1998, as exportações estão concentradas no 
grupo “setores em situação ótima” e “setores em declínio”. Já em 2001-2005, cresceu a participação das exportações nesses grupos, em detrimento dos grupos "setores em retrocesso" e "oportunidades perdidas", sendo que o aumento observado no grupo "setores em situação ótima" foi mais significativo. Considerando a participação das exportações nos grupos dinâmicos, no período 1994-1998, a China apresentou uma participação ligeiramente maior em setores não dinâmicos do mercado mundial, igual a $54,3 \%$, sendo a participação em setores dinâmicos igual a 45,7\%. No segundo período, ocorre uma inversão quase exata desses valores, e a China passa a apresentar uma parcela de suas exportações ligeiramente mais elevada em setores dinâmicos do mercado mundial.

Tabela 7: Participação Relativa das Exportações segundo o

Dinamismo e Competitividade - China - 1994-1998 e 2001-2005

\begin{tabular}{lcccc}
\hline Setor/ País & Setor & País & 1994-1998 & 2001-2005 \\
\hline Setores em Situação Ótima & Dinâmico & Competitivo & $43,9 \%$ & $51,9 \%$ \\
Setores em Declínio & Não-dinâmico & Competitivo & $44,4 \%$ & $45,0 \%$ \\
Oportunidades Perdidas & Dinâmico & Não-competitivo & $1,8 \%$ & $2,2 \%$ \\
Setores em Retrocesso & Não-dinâmico & Não-competitivo & $10,0 \%$ & $0,9 \%$ \\
\hline TOTAL & & & $100,0 \%$ & $100,0 \%$ \\
\hline
\end{tabular}

Fonte: Elaboração própria, a partir de COMTRADE/ UNCTAD.

A participação em setores não-dinâmicos do mercado mundial, no caso do grupo "setores em declínio", no qual esteve concentrada quase metade das exportações da China, é uma situação desfavorável se a redução da participação relativa das exportações mundiais nesses setores se revelar uma tendência permanente, pois nesse caso, o país está deslocando recursos de sua economia para setores não dinâmicos e deixando de exportar em setores com uma demanda mundial crescente, o que pode confluir para um aumento das exportações concentradas no grupo “oportunidades perdidas". Por outro lado, se a queda da demanda mundial nesses setores for resultado de mudanças conjunturais que podem significar uma reversão dessa trajetória, então, o fato do país estar se tornando mais competitivo nesses setores deixa de ser um resultado negativo. A interpretação dos resultados obtidos para o grupo "setores em situação ótima" é mais óbvia. Trata-se de uma situação claramente favorável para o país, pois ele está se tornando mais competitivo em setores nos quais a demanda mundial cresceu.

Portanto, os resultados obtidos apontaram para uma melhora da posição relativa de market-share e, ao mesmo tempo, uma piora dessa posição. Para interpretar tais resultados, resta verificar quais setores pertencem aos grupos da matriz 
de competitividade. ${ }^{6}$ Os setores classificados no grupo "setores em situação ótima" correspondem, principalmente, aos produtos de mais alta intensidade tecnológica: capítulo 7, referente a máquinas e equipamentos de transporte, que possui as maiores participações relativas nas exportações mundiais, e os capítulos 5, 6 e 8 , referentes aos produtos químicos e manufaturados diversos, segundo a classificação SITC. Já o grupo “oportunidades perdidas”, no período de 1994-1998, consistiu de alguns importantes setores do capítulo 5 e 7, mas no período mais recente, os setores nessa posição são, em geral, baseados em recursos naturais, e, portanto, de mais baixo valor agregado. Nesse sentido, é interessante para o país aumentar a participação de suas exportações concentradas no grupo "situação ótima" ao invés de "oportunidades perdidas".

Pode-se dizer que o padrão de especialização comercial da China convergiu à estrutura das exportações mundiais, uma vez que apresentou uma maior participação de suas exportações em setores dinâmicos do mercado mundial. Após verificar quais setores pertencem ao grupo "situação ótima", pode-se dizer que os resultados obtidos confirmam mais uma vez as mudanças na estrutura de exportações da China em direção aos setores de mais alta intensidade tecnológica.

A análise da evolução da taxa de crescimento das exportações mundiais, segundo o relatório da UNCTAD (2002), no período de 1980-1998, apontou para o maior dinamismo dos setores de alta intensidade tecnológica, o que está relacionado com fatores que vão além das diferenças em termos de elasticidade-renda dos produtos. As políticas de abertura econômica nos países em desenvolvimento tiveram papel importante, privilegiando os setores mais intensivos em tecnologia sobre as commodities primárias. Além disso, os incentivos à entrada de capitais estrangeiros ampliaram as redes de produção internacionais em vários produtos, levando a fragmentação dos processos produtivos em vários países. De outro lado, os países desenvolvidos abriram seus mercados aos produtos processados nas redes de produção globais localizadas nos países em desenvolvimento. Nesse sentido, as exportações em setores mais intensivos em tecnologia pelos países em desenvolvimento podem significar a exploração de vantagens comparativas locais, como o baixo custo de mão de obra, especializando-se em fases de mais baixo valor agregado da cadeia produtiva, enquanto as etapas mais intensivas em tecnologia permanecem concentradas nos países desenvolvidos.

Portanto, a maior participação dos países em desenvolvimento no comércio mundial e, mais do que isso, a mudança da composição setorial das exportações em direção aos setores de mais alta intensidade tecnológica, em detrimento das commodities primárias, pode não ter sido acompanhada por um crescimento do PIB dessas economias, indicando que não houve convergência para renda dos países desenvolvidos. À exceção de alguns países do Leste Asiático, apesar da amplia-

\footnotetext{
${ }^{6}$ Essa interpretação é sugerida em Martins (2004).
} 
ção de participação dos países em desenvolvimento em termos das exportações de manufaturas, não houve a ampliação correspondente em termos da renda e produção mundial de manufaturas, pois esses países estiveram concentrados em etapas do processo de produção de baixo valor agregado. Em relação à China, seu resultado é positivo em termos de ampliação de sua participação no total da renda mundial no setor de manufaturas (3,3\% em 1980 contra 5,8\% em 1997), mas seu desempenho é pouco expressivo se comparado com seu crescimento no comércio mundial desses produtos. (Ibid., p. 81)

Nesse ponto, o trabalho de Rodrik (2006) fez uma avaliação positiva do padrão de especialização comercial da China em termos de seus efeitos sobre o crescimento econômico, a partir do cálculo da produtividade dos setores de exportação da China, argumentando que a China se especializou em setores do comércio internacional de alta produtividade, altamente sofisticados, comum à especialização de países desenvolvidos, com um nível de renda per capita três vezes maior que o da China. Os resultados obtidos, através de um modelo de equilíbrio geral e utilizando o ferramental econométrico, mostram uma associação positiva entre a produtividade das exportações da China e seu crescimento per capita (PIB per capita), no sentido de que este último está convergindo ao nível de produtividade das exportações. Isso se deve a um movimento de difusão dos ganhos de produtividade ao longo dos setores da economia, deslocando os recursos para os setores de exportação de alta produtividade. Ao mesmo tempo, o autor chama a atenção para os limites desses ganhos de produtividade, pois uma vez que a estrutura das exportações mudou em direção aos setores de mais alta produtividade, a manutenção de patamares elevados de crescimento irá depender da capacidade da economia chinesa de "descobrir" novos produtos de sucesso exportador.

\section{CONSIDERAÇÕES FINAIS}

A breve revisão de literatura que tratou da interação entre comércio exterior e fluxos de investimento direto externo (IDE) na economia chinesa mostrou a importância da seletividade na política de abertura comercial e da articulação entre fluxos de IDE e fluxos de comércio, para entender os movimentos observados na estrutura de exportações da China, tanto em termos quantitativos, como em termos qualitativos. Nesse contexto, o sistema comercial que privilegiou a indústria de reexportação, ao conceder isenção tarifária aos insumos importados utilizados para exportação de bens finais, foi determinante do processo de reconfiguração das cadeias de produção na região asiática, com o envolvimento crescente da China. Portanto, os saldos comerciais fortemente positivos observados no comércio exterior da China neste início de século XXI estão diretamente correlacionados com a presença dos fluxos internacionais de capitais produtivos. 
A análise do padrão de especialização comercial chinês mostrou que, de fato, a China se tornou mais competitiva nos setores mais intensivos em tecnologia, principalmente, nos anos 2000, ainda que os setores intensivos em trabalho tenham revelado um desempenho superior ao das demais indústrias, tanto em termos do indicador de VCR como o indicador de CS. Ademais, as mudanças na estrutura de exportações em direção aos setores mais intensivos em tecnologia conformaram um padrão de especialização comercial dinâmico, na medida em que a China ampliou sua participação de mercado naqueles setores que apresentaram uma evolução positiva da taxa de crescimento médio no comércio internacional. Portanto, para além da atuação dos fluxos de IDE explorando as vantagens comparativas da China em termos de abundância de mão de obra, os resultados demonstram que a China melhorou sua eficiência produtiva e está avançando na construção de capacidades tecnológicas, desenvolvendo uma indústria de alta tecnologia e consolidando sua posição em tais setores no mercado internacional.

\section{REFERÊNCIAS BIBLIOGRÁFICAS}

BALASSA, Bela (1965) "Trade liberalization and "revealed" comparative advantage". The Manchester School, v. XXXIII, n. ${ }^{\circ}$ 2: 99-123.

BAUMANN, Renato \& NEVES, Luis Felipe Castro (1998) “Abertura, barreiras comerciais externas e desempenho exportador brasileiro". CEPAL - Brasil.

BRANSLETTER, Lee \& LARDY, Nicholas (2006) “China's embrace of globalization” NBER Working Paper 12373.

EICHENGREEN, Barry \& RHEE, Yeongseop \& TONG, Hui (2004) “The impact of China on the exports of other Asian countries". NBER, Working Paper 10768. Cambridge.

HOLLAND, Márcio \& XAVIER, Clésio Lourenço (2004) "Dinâmica e competitividade das exportações brasileiras: uma análise de painel para o período recente”. In: Encontro Nacional de Economia, 32, João Pessoa, PB. Anais da ANPEC. (Disponível em CD-ROM).

(IDB) INTER-AMERICAN DEVELOPMENT BANK (2005) “The emergence of China: Opportunities and challenges for Latin America and the Caribbean".

LAFAY, G. (1990) “La mesure des avantages comparatifs révélés: exposé de la méthodologie du CEPII”. Économie Prospective Internacionale, p. 27-43.

LALL, Sanjaya (2000) "Export performance, technological upgrading and foreign direct investment strategies in the Asian newly industrializing economies”. CEPAL, Santiago, Chile.

LAPLANE, M. F., SARTI, F. HIRATUKA, C., SABBATINI, R. C. (2001) “O caso brasileiro”. In: CHUDNOVSKY, D. (coord.), El Boom de las Inversiones Extranjeras Directas en el Mercosur. Buenos Aires, Siglo XXI.

LEMOINE, Françoise \& ÜNAL-KESENCI, Deniz (2002) "China in the International segmentation of production processes”. CEP II, n. ${ }^{\circ} 2002-02$.

LU, Ding (2000) "Industrial policy and resource allocation: implications on China's participation in globalization”. China Economic Review 11: 342-360.

LUNDVALL, Bengt-Ake \& GU, Shulin (2006) “China's innovation system and the move towards harmonious growth and endogenous innovation”. DRUID Working Paper 06-7. 
MARTINS, Marcilene Aparecida (2004) “O comércio exterior brasileiro nos anos 1980 e 1990: Estrutura e evolução do padrão de especialização”. Tese (Doutorado em Economia). UNICAMP, Campinas.

ORGANIZAÇÃO MUNDIAL DO COMÉRCIO (OMC). (2006) World Trade Policy Review. China.

PAVITT, Keith. (1984) "Sectoral patterns of technical change: towards a taxonomy and a theory". Research Policy, v. 13.

RODRIK, Dani (2006) “What's so special about China's exports?” NBER Working Paper 11947, Cambridge.

RUMBAUGH, Thomas \& BLANCHER, N. (2004) "China: international trade and WTO accession". IMF Working Paper.

(UNCTAD) UNITED NATIONS CONFERENCE ON TRADE AND DEVELOPMENT. (2002) “Trade and Development Report - Part II".

XAVIER, Clésio Lourenço (2000) "Padrões de especialização e competitividade no exterior brasileiro". Tese (Doutorado em Economia). UNICAMP, Campinas. 